\title{
Analisis Berpikir Literasi Matematika Berdasarkan Kemandirian Belajar Siswa SMP
}

\author{
Shelly Agustiani ${ }^{1 *}$, Nur Agustiani ${ }^{2}$, Novi Andri Nurcahyono ${ }^{3}$ \\ 1) 2) 3) Pendidikan Matematika, FKIP Universitas Muhammadiyah Sukabumi \\ 1) agstianisel@gmail.com \\ 2) nuragustiani@ummi.ac.id \\ 3)nanurcahyono@gmail.com
}

\begin{abstract}
ABSTRAK
Kemampuan berpikir literasi matematika merupakan salah satu keterampilan abad 21 yang penting untuk dimiliki oleh siswa. Tujuan dari penelitian ini yaitu untuk mendeskripsikan kemampuan berpikir literasi matematika siswa SMP berdasarkan kemandirian belajar. Jenis penelitian ini adalah studi kasus dengan pendekatan kualitatif deskriptif. Subjek penelitian terdiri dari 3 orang siswa kelas VIII pada salah satu MTs. di Kota Sukabumi di mana setiap siswa mewakili masing-masing kategori kemandirian belajar, yaitu: rendah, sedang dan tinggi. Pengumpulan data menggunakan metode angket, tes serta wawancara. Hasil penelitian ini yaitu: 1) Siswa dengan kemandirian belajar rendah memenuhi dua indikator dari menafsirkan, menerapkan dan mengevaluasi hasil matematika, 2) Siswa dengan kemandirian belajar sedang memenuhi semua indikator dari merumuskan situasi secara matematis dan menerapkan konsep matematika, fakta, prosedur dan penalaran matematika 3) Siswa dengan kemandirian belajar tinggi memenuhi semua indikator proses berpikir literasi matematika.
\end{abstract}

Kata Kunci: Analisis, Berpikir Literasi Matematika, Kemandirian Belajar.

\begin{abstract}
Mathematical literacy thinking ability is one of the $21^{\text {st }}$ century skills that are most important owned by students. This study aims to describe the mathematical literacy thinking skills of junior high school students based on independent learning. This is the kind of research is a case study with a descriptive qualitative approach. The subject in this study consisted of three students of class VIII at one of the MTs in Sukabumi city where every student represents each category of learning independence, which is low, medium and high. Data collection techniques are carried out by providing questionnaires, tests and interviews. The result of this study is: 1) students with low learning independence only filled two an indicator of interpreting, applying and evaluating mathematical result, 2) students with moderate learning independence have fulfilled all the indicators of formulating situations mathematically and applying mathematical concepts, facts, procedures and mathematical reasoning, 3) students with high learning independence fulfilled all indicators of the mathematical literacy thinking process.
\end{abstract}

Keywords: Analysis, Thinking in Mathematical Literacy, Learning Independence.

\section{A. PENDAHULUAN}

Matematika merupakan salah satu mata pelajaran yang dipelajari hampir di semua jenjang pendidikan. Matematika juga merupakan salah satu ilmu dasar yang bermanfaat dan berguna untuk kehidupan sehari-hari. Pelajaran matematika di sekolah berperan penting untuk memecahkan masalah baik dalam sekolah, dunia kerja maupun kehidupan sehari-hari (Kholifasari dkk., 2020). 
Oleh karena itu matematika penting untuk dipelajari oleh siswa. Pada saat ini tujuan untuk mempelajari matematika yaitu, siswa diharapkan tidak hanya memiliki kemampuan berhitung atau menggunakan rumus saja tetapi harus mempunyai kemampuan bernalar dan berpikir matematis yang dapat digunakan untuk memecahkan masalah dalam kehidupan seharihari (Indrawati \& Wardono, 2019). Saat ini siswa tidak hanya dituntut untuk bisa berhitung saja tetapi juga mempunyai kemampuan bernalar yang kritis dan juga logis yang dapat digunakan untuk memecahkan permasalahan dalam kehidupan sehari-hari. Kemampuan tersebut merupakan kemampuan literasi matematika (Sari, 2015). Oleh karena itu mempunyai kemampuan berpikir literasi matematika penting untuk dimiliki oleh siswa agar dapat membantu memecahkan permasalahan yang terjadi di kehidupannya.

Menurut (Anwar, 2018) kemampuan literasi matematika adalah kemampuan yang dimiliki suatu individu dalam menggunakan matematika untuk menyelesaikan permasalahan di kehidupan sehari-hari secara efektif yaitu dimulai dengan memahami masalah, merumuskannya, menggunakan pengetahuan matematikanya dalam menyelesaikan masalah serta menginterpretasikan. Memiliki kemampuan literasi matematika yang baik dapat membantu seseorang untuk menggunakan dan menerapkan matematika ke dalam berbagai konteks (OECD, 2019). Kemampuan literasi matematika juga penting untuk dimiliki siswa karena terdapat empat komponen penting dalam literasi matematika yang dapat ditemui pada keterampilan abad 21 yaitu memahami konsep, memecahkan masalah, mengkomunikasikan dan menerapkan prosedur (Anwar, 2018).

Kemampuan yang penting untuk dimiliki siswa salah satunya yaitu kemampuan berpikir literasi matematika. Namun kenyataannya, siswa di Indonesia mempunyai literasi matematika yang terbilang masih belum memuaskan. Hal tersebut dapat dilihat berdasarkan hasil penelitian yang dilakukan pada tahun 2018 oleh Programme for International Student Assessment (PISA) yang diselenggarakan Organization for Economic Cooperation and Development (OECD) dimana Indonesia berada di peringkat 73 dari 79 negara pada kategori literasi matematika (OECD, 2019). Hal tersebut sejalan dengan penelitian Astuti dkk. (2018) bahwa kemampuan literasi matematika siswa kelas VIII SMP swasta pada salah satu kota di Indonesia secara umum masih terbilang rendah berdasarkan rata-rata nilai yang diperoleh yaitu 19,87 dari 100 .

Sejalan dengan hal tersebut berdasarkan analisis pendahuluan yang dilakukan menunjukkan bahwa pada salah satu MTs di Kota Sukabumi kemampuan berpikir literasi matematika siswa masih terbilang rendah. Hasil wawancara dengan salah satu guru matematika di salah satu MTs di Kota Sukabumi diketahui bahwa sebagian besar siswa masih kesulitan dalam menyelesaikan masalah dalam bentuk 
soal cerita yang berkaitan dengan kehidupan sehari-hari terutama pada materi SPLDV. Kebanyakan siswa masih belum dapat mengidentifikasi soal dan kesulitan dalam mengubahnya ke dalam bentuk matematika. Bahkan beberapa siswa kesulitan dalam memahami permasalahan yang ada pada soal. Pada soal cerita terdapat empat kemampuan literasi dalam pemecahan masalah (Utami dkk., 2020). Hal tersebut berarti kemampuan literasi matematika siswa masih terbilang rendah.

Rendahnya kemampuan literasi matematika siswa dapat banyak disebabkan oleh banyak faktor. Salah satunya yaitu kemandirian belajar. Kemandirian belajar memberikan pengaruh terhadap kemampuan literasi matematika siswa pada pembelajaran DAPIC-Problem-Solving (Wijayanti \& Wardono, 2020). Hal tersebut sejalan dengan penelitian Kholifasari dkk. (2020) bahwa rendahnya kemampuan literasi matematika dapat disebabkan karena jarangnya siswa diberikan soal yang mengacu pada literasi matematika dan juga karena rendahnya kemandirian belajar siswa. Hal tersebut berarti tinggi rendahnya kemandirian belajar siswa dapat memberikan pengaruh terhadap kemampuan literasi matematikanya.

Berdasarkan pemaparan di atas, maka perlu adanya penelitian mengenai bagaimana berpikir literasi matematika siswa berdasarkan kemandirian belajar yang dibagi ke dalam tiga kategori, yaitu: rendah, sedang dan tinggi. Hal tersebut dilakukan untuk mengetahui ketercapaian siswa terhadap indikator berpikir literasi matematika berdasarkan kemandirian belajar pada kategori rendah, sedang dan tinggi. Hal tersebut diharapkan dapat menjadi bahan pertimbangan guru atau sekolah dalam upaya membantu atau memperbaiki kemampuan berpikir literasi matematika berdasarkan kemandirian belajar siswa. Tujuan dari penelitian ini yaitu untuk mendeskripsikan kemampuan berpikir literasi matematika siswa SMP kelas VIII berdasarkan kemandirian belajar.

\section{B. METODE}

Metode penelitian yang digunakan adalah studi kasus dengan pendekatan kualitatif. Penelitian ini dilakukan pada bulan Januari 2021 sampai Mei 2021 pada kelas VIII salah satu MTs di Kota Sukabumi yang terdiri dari 33 siswa. Adapun teknik pengumpulan data yang dilakukan dalam penelitian ini terdiri dari angket, tes dan wawancara. Pengambilan data tersebut dilakukan secara luring. Angket yang digunakan pada penelitian ini menggunakan indikator kemandirian belajar yang diadaptasi dari beberapa ahli terdiri dari: inisiatif belajar dengan atau tanpa bantuan orang lain; melakukan kontrol diri; mendiagnosis kebutuhan belajarnya; dapat bekerja sama dengan orang lain; membangun makna; mengevaluasi hasil belajarnya dan memilih strategi belajar; menggunakan dan memilih sumber yang relevan; dan menetapkan target dan tujuan belajar. Sebelum diberikan kepada siswa angket kemandirian belajar divalidasi terlebih dahulu oleh 3 orang ahli. Hasil jawaban siswa terhadap angket digunakan untuk 
mengklasifikasikan kategori kemandirian belajar yang dimiliki masing-masing siswa. Angket pada penelitian ini berjumlah 32 pernyataan yang terdiri dari masing-masing 16 pernyataan positif dan negatif yang sesuai dengan indikator kemandirian belajar. Penilaian pada penelitian ini menggunakan skala likert dengan 4 titik pilihan yang terdiri dari sangat sesuai (SS), sesuai (S), tidak sesuai (TS) dan sangat tidak sesuai (STS). Hasil jawaban siswa terhadap angket kemandirian belajar kemudian diklasifikasikan ke dalam tiga kategori yaitu rendah, sedang dan tinggi.

Berdasarkan hasil angket, dipilih 3 orang siswa yang mewakili masing-masing kategori kemandirian belajar yaitu: rendah, sedang dan tinggi. Yang ditentukan dengan menggunakan purposive sampling yaitu teknik pengambilan subjek berdasarkan pertimbangan tertentu. Dimana subjek penelitian terdiri dari siswa yang mewakili masing-masing kategori kemandirian belajar yaitu: rendah, sedang dan tinggi dan juga berdasarkan pertimbangan dari guru. Selanjutnya memberikan tes literasi matematika kepada siswa dengan materi Sistem Persamaan Linear Dua Variabel (SPLDV). Tes literasi matematika yang digunakan berupa soal uraian yang berjumlah dua buah. Sama halnya dengan angket sebelum diberikan kepada siswa instrumen tes divalidasi terlebih dahulu oleh tiga orang ahli. Adapun soal tes yang digunakan pada penelitian ini adalah sebagai berikut.
1. Pak Dono memelihara ayam dan sapi di rumahnya sebanyak 14 ekor. Jika jumlah kaki ayam dan sapi yang ia pelihara terdiri dari 36 kaki. Berapa jumlah masing-masing ayam dan sapi yang dipelihara pak Dono?

2. Seorang pengrajin kayu membuat sebuah rak buku dengan 3 macam ukuran yaitu kecil, sedang dan besar. Untuk 1 rak buku kecil dijual dengan harga Rp. 200.000 dengan keuntungan sebesar Rp. 56.000 dan bahan yang dibutuhkan adalah 4 papan dan 16 paku kayu. Untuk 1 rak buku sedang dijual dengan harga Rp. 300.000 dengan keuntungan sebesar Rp. 80.500 dan bahan yang dibutuhkan yaitu 6 papan dan 38 paku kayu. Untuk 1 rak buku besar membutuhkan 15 papan dan 230 paku kayu. Jika penjual ingin mendapatkan keuntungan sebesar Rp. 167.500. Berapakah harga rak buku besar tersebut?

Soal tersebut merupakan instrumen tes yang digunakan pada penelitian ini. Untuk soal nomor 1 merupakan soal kemampuan literasi matematika level 1 (rendah). Untuk soal nomor 2 merupakan soal kemampuan literasi matematika level 3 (sedang).

Hasil tes dari ketiga subjek penelitian tersebut kemudian dianalisis dengan menggunakan indikator berpikir literasi matematika yang diadaptasi dari penelitian Aini dkk. (2018) yaitu sebagai berikut. 
Tabel 1. Indikator Berpikir Literasi Matematika

\begin{tabular}{|c|c|c|}
\hline No. & $\begin{array}{l}\text { Komponen Proses } \\
\text { Berpikir Literasi }\end{array}$ & Indikator Berpikir Literasi \\
\hline \multirow{4}{*}{1} & \multirow{4}{*}{$\begin{array}{l}\text { Merumuskan situasi } \\
\text { secara matematis }\end{array}$} & Mengidentifikasi konsep dalam permasalahan \\
\hline & & Menggambarkan situasi matematis dengan menggunakan simbol \\
\hline & & Menemukan hubungan antar variabel berdasarkan fakta \\
\hline & & Membuat model matematika berdasarkan permasalahan \\
\hline \multirow{3}{*}{2} & \multirow{3}{*}{$\begin{array}{l}\text { Menerapkan konsep } \\
\text { matematika, fakta, } \\
\text { prosedur dan } \\
\text { penalaran matematika }\end{array}$} & Merancang strategi dalam menemukan solusi \\
\hline & & $\begin{array}{l}\text { Menerapkan fakta, operasi, algoritma dan struktur saat } \\
\text { menemukan solusi }\end{array}$ \\
\hline & & Menemukan pola, mengolah data dan informasi \\
\hline \multirow{3}{*}{3} & \multirow{3}{*}{$\begin{array}{l}\text { Menafsirkan, } \\
\text { menerapkan dan } \\
\text { mengevaluasi hasil } \\
\text { matematika }\end{array}$} & $\begin{array}{l}\text { Menginterpretasikan kembali hasil pemecahan masalah ke dalam } \\
\text { konteks nyata }\end{array}$ \\
\hline & & Menyimpulkan dari permasalahan yang diberikan \\
\hline & & Mengevaluasi hasil matematika \\
\hline
\end{tabular}

Tabel 1 tersebut menjelaskan mengenai indikator berpikir literasi menurut Aini dkk. (2018) yang terdiri dari tiga komponen proses berpikir literasi matematika. Pada penelitian ini indikator tersebut digunakan untuk mengetahui berpikir literasi matematika siswa dengan kategori kemandirian belajar yaitu: rendah, sedang dan tinggi. Selanjutnya subjek diwawancara mengenai hasil jawabannya terhadap tes literasi matematika. Pada penelitian ini dilakukan keabsahan data dengan menggunakan triangulasi teknik. Analisis data dilakukan dalam dua tahap yang terdiri dari analisis data sebelum di lapangan dan setelah di lapangan. Analisis data sebelum di lapangan terdiri dari analisis pendahuluan. Sedangkan analisis data setelah di lapangan terdiri dari mereduksi data, menyajikan data terakhir menarik kesimpulan.

\section{HASIL DAN PEMBAHASAN}

Berdasarkan hasil jawaban siswa terhadap angket kemandirian belajar, selanjutnya dipilih tiga orang siswa yang mewakili masing-masing kategori kemandirian belajar yaitu: rendah, sedang dan tinggi. Setelah siswa diberikan angket kemandirian belajar, selanjutnya siswa diberikan tes matematika yang terdiri dari dua soal esai materi SPLDV. Setelah subjek menyerahkan hasil jawabannya, selanjutnya dilakukan wawancara. Jawaban siswa terhadap tes dianalisis berdasarkan komponen proses berpikir literasi matematika.

Berdasarkan hasil jawaban ketiga subjek di atas dapat diketahui bahwa terdapat perbedaan ketercapaian indikator kemampuan berpikir literasi matematika pada siswa dengan kategori kemandirian belajar yaitu, rendah, sedang dan tinggi adalah sebagai berikut: 
Tabel 2. Perbedaan Berpikir Literasi Matematika Siswa Berdasarkan Kemandirian Belajar

\begin{tabular}{|c|c|c|c|c|}
\hline \multirow{2}{*}{ Komponen Proses Berpikir literasi } & \multirow{2}{*}{$\begin{array}{l}\text { Indikator } \\
\text { ke }\end{array}$} & \multicolumn{3}{|c|}{ Kemandirian belajar } \\
\hline & & Rendah & Sedang & Tinggi \\
\hline \multirow{4}{*}{ Merumuskan situasi secara matematis } & 1 & - & $\sqrt{ }$ & V \\
\hline & 2 & - & $\sqrt{ }$ & V \\
\hline & 3 & - & $\mathrm{V}$ & $\sqrt{ }$ \\
\hline & 4 & - & $\sqrt{ }$ & $\mathrm{V}$ \\
\hline \multirow{3}{*}{$\begin{array}{l}\text { Menerapkan konsep matematika, fakta, prosedur } \\
\text { dan penalaran matematika }\end{array}$} & 1 & - & $\mathrm{V}$ & $\mathrm{V}$ \\
\hline & 2 & - & $\mathrm{V}$ & $\mathrm{V}$ \\
\hline & 3 & - & V & V \\
\hline \multirow{3}{*}{$\begin{array}{l}\text { Menafsirkan, menerapkan dan mengevaluasi hasil } \\
\text { matematika }\end{array}$} & 1 & - & $\sqrt{ }$ & V \\
\hline & 2 & $\sqrt{ }$ & - & $\mathrm{V}$ \\
\hline & 3 & v & - & V \\
\hline
\end{tabular}

Berdasarkan tabel 2 tersebut dapat diketahui bahwa siswa dengan kemandirian belajar tinggi memenuhi semua indikator dari komponen proses berpikir literasi. Siswa dengan kemandirian belajar sedang memenuhi semua indikator dari kedua komponen proses berpikir literasi. Namun pada komponen proses berpikir literasi yang ketiga hanya satu indikator yang terpenuhi. Sedangkan untuk siswa dengan kemandirian belajar rendah hanya memenuhi dua indikator komponen proses berpikir literasi.

Adapun hasil analisis jawaban dari ketiga subjek penelitian terhadap indikator proses berpikir literasi matematika adalah sebagai berikut:

\section{Siswa dengan Kategori Kemandirian Belajar Rendah (Siswa KR)}

Berdasarkan hasil jawaban KR terhadap soal tes terlihat bahwa siswa belum memenuhi semua indikator dari komponen yang pertama. Adapun hasil jawaban KR adalah sebagai berikut.

\section{Banyak sapi adalah $=4$ Banyak Ayam adalah $=10$}

Gambar 1. Kutipan Jawaban KR

Berdasarkan gambar 1 dapat diketahui bahwa KR tidak merumuskan situasi secara sistematis. Dimana KR tidak mengidentifikasi konsep SPLDV yang ada pada permasalahan. KR juga tidak menggambarkan situasi matematis dengan menggunakan simbol dan tidak menemukan hubungan antar variabel berdasarkan fakta yang ada pada soal serta tidak membuat model matematika berdasarkan informasi yang ada pada soal. Hal tersebut terlihat dari jawaban KR pada gambar 1 dimana siswa hanya menuliskan banyak sapi adalah 4 dan ayam adalah 10 tanpa mencantumkan langkah-langkah penyelesaiannya. Hal tersebut sejalan dengan penelitian Mayasari \& Rosyana (2019) bahwa siswa tidak menuliskan apa yang diketahui dan ditanyakan pada soal dimana hal tersebut termasuk rendahnya kemandirian 
belajar siswa pada indikator menginterpretasikan atau menjelaskan hasil sesuai permasalahan pada soal. Penelitian Sulistyani dkk. (2020) bahwa siswa dengan kemandirian belajar rendah tidak mampu menyajikan permasalahan yang ada pada soal ke dalam model matematika.

Selain tidak memenuhi indikator merumuskan situasi secara sistematis, KR juga tidak memenuhi indikator dari komponen yang kedua. Dapat dilihat pada gambar 1 bahwa KR tidak merancang sebuah strategi untuk menjawab pertanyaan tersebut. KR juga tidak mengolah data serta informasi yang ada untuk memecahkan permasalahan yang ada pada soal. KR hanya menggunakan petunjuk pada soal untuk menemukan solusi. Dimana KR menuliskan kesimpulan dari jawabannya dengan tepat tetapi tidak mencantumkan langkahlangkah perhitungannya. Hal tersebut sejalan dengan penelitian Arum (2017) bahwa dalam menyelesaikan soal siswa dengan kemandirian belajar rendah belum mampu menuliskan alasan yang mendukung jawabannya.

Untuk komponen yang ketiga KR hanya memenuhi dua indikator saja. Terlihat dari hasil jawaban KR pada gambar 1 bahwa siswa tidak menginterpretasikan hasil pemecahan masalahnya. Namun, siswa hanya menuliskan hasil akhir jawabannya untuk permasalahan yang ada pada soal serta jawaban yang diberikan sudah benar dan tepat.

Hasil wawancara KR sejalan dengan pemaparan-pemaparan di atas dimana siswa merasa kesulitan untuk menuliskan langkahlangkah penyelesaian yang mendukung jawabannya serta kurang memahami mengenai materi SPLDV. Dimana KR tidak menerapkan atau menggunakan konsep dari materi SPLDV dalam menyelesaikan soal tersebut.

Berdasarkan hasil analisis jawaban dan wawancara dapat diketahui bahwa KR (siswa dengan kategori kemandirian belajar rendah) tidak memenuhi semua indikator pada komponen proses berpikir literasi yang pertama dan kedua. Tetapi sudah memenuhi beberapa indikator dari satu komponen proses berpikir literasi matematika. Dimana siswa tidak merumuskan situasi yang ada pada soal secara matematis dan tidak menggunakan strategi untuk menyelesaikan permasalahan tersebut. Tetapi siswa hanya menuliskan kesimpulan dari hasil jawabannya tanpa menyertakan alasan yang mendukung jawabannya.

Hal tersebut sejalan dengan penelitian Ekananda dkk. (2020) bahwa siswa dengan level kemandirian belajar rendah dalam proses pengerjaan soalnya belum baik dan relatif tidak terstruktur serta belum mengetahui cara untuk melakukan proses pemecahan masalahnya. Oleh karena itu dapat diketahui bahwa siswa dengan kemandirian rendah mempunyai kemampuan berpikir literasi matematika yang masih tergolong rendah. 


\section{Siswa dengan Kategori Kemandirian Belajar} Sedang (Siswa KS)

Berdasarkan hasil jawaban KS terhadap soal tes terlihat bahwa untuk komponen proses berpikir literasi yang pertama siswa sudah memenuhi semua indikator. Adapun hasil jawaban KS adalah sebagai berikut.

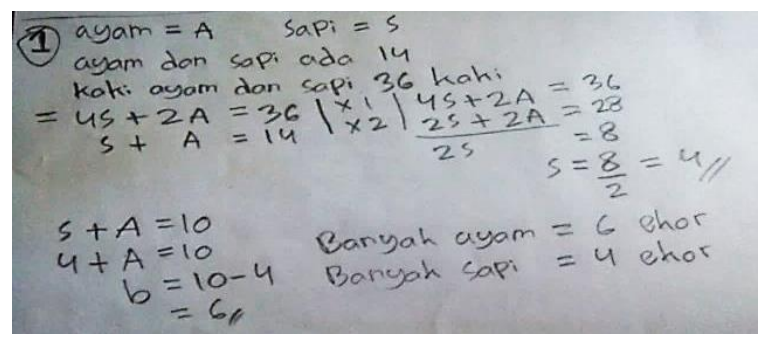

Gambar 2. Kutipan Jawaban KS

Berdasarkan gambar 2 diketahui bahwa KS sudah merumuskan situasi secara matematis. Dimana KS mengidentifikasi konsep SPLDV yang ada pada permasalahan dengan memisalkan ayam dan sapi dengan variabel. KS juga menggambarkan situasi matematis dengan mengubah permasalahan yang ada pada soal menjadi bentuk model matematika. Dengan menggunakan petunjuk dan informasi yang ada pada soal KS menemukan hubungan antar variabel. Persamaan yang dituliskan oleh KS sudah tepat dan sesuai dengan informasi yang ada pada soal.

KS juga sudah memenuhi semua indikator untuk komponen yang kedua. Hal tersebut terlihat dari gambar 2 bahwa KS menggunakan metode eliminasi dan substitusi untuk memecahkan permasalahan yang ada pada soal. KS juga menerapkan informasi yang ada pada soal dan mengubahnya ke dalam bentuk persamaan. persamaan tersebut kemudian digunakan dalam langkah-langkah penyelesaiannya untuk memecahkan permasalahan pada soal.

Untuk komponen yang ketiga KS hanya memenuhi 1 indikator. Hal tersebut terlihat dari gambar 2 bahwa KS sudah menginterpretasikan hasil pemecahan masalahnya ke dalam konteks nyata serta menyelesaikan langkah-langkah penyelesaiannya. Namun jawaban yang diberikan oleh KS belum tepat karena salah menuliskan salah satu persamaan. KS menuliskan persamaan $s+a=10$ seharusnya yaitu $s+a=14$. Oleh karena itu jawaban dari siswa KS masih belum tepat. Hal tersebut sejalan dengan penelitian Sulistyani dkk. (2020) bahwa siswa dengan kemandirian belajar sedang melakukan kesalahan dalam melakukan perhitungan sehingga menyebabkan hasil jawaban yang kurang tepat. Penelitian Ekananda dkk. (2020) menyatakan bahwa siswa memahami permasalahan yang ada pada soal, namun pada proses perhitungan siswa dengan kemandirian belajar sedang melakukan kesalahan kecil dikarenakan kurang teliti dan merasa waktu yang diberikan dirasa singkat.

Hasil wawancara KS sejalan dengan pemaparan-pemaparan di atas. Dimana KS sudah mengetahui permasalahan pada soal serta cara untuk menyelesaikannya. Hanya saja dikarenakan waktu yang dianggap kurang KS melakukan beberapa kesalahan dan tidak memeriksa ulang hasil jawabannya. Berdasarkan pemaparan-pemaparan di atas dapat diketahui 
bahwa siswa dengan kemandirian belajar sedang (siswa KS) sudah memenuhi semua indikator dari merumuskan situasi secara matematis serta menerapkan konsep matematika, fakta, prosedur dan penalaran matematika. Tetapi untuk indikator menafsirkan, menerapkan dan mengevaluasi hasil matematika siswa melakukan kesalahan dalam membuat model matematika yang menyebabkan jawabannya kurang tepat. Siswa juga tidak menyadari adanya kesalahan dari jawabannya sehingga tidak memperbaikinya. Hal tersebut sejalan penelitian Arum (2017) bahwa siswa dengan kemandirian belajar sedang sudah memahami permasalahan yang ada pada soal, mampu menemukan strategi yang tepat untuk menyelesaikan soal, memberikan alasan yang mendukung atas hasil jawabannya serta siswa melakukan beberapa kesalahan dalam menyelesaikan jawabannya. Oleh karena itu dapat diketahui bahwa KS (siswa dengan kategori kemandirian belajar sedang) mempunyai kemampuan berpikir literasi matematika yang tergolong sedang.

\section{Siswa dengan kategori kemandirian belajar tinggi (KT)}

Berdasarkan hasil jawaban KT terhadap soal tes terlihat bahwa untuk komponen proses berpikir literasi yang pertama siswa sudah memenuhi semua indikator. Adapun hasil jawaban KT adalah sebagai berikut.

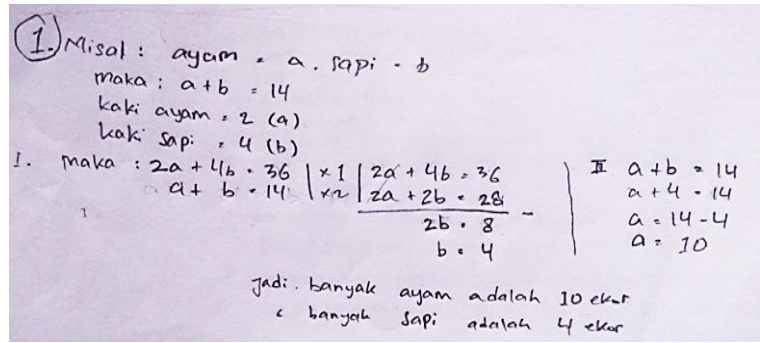

Gambar 3. Kutipan Jawaban KT

Berdasarkan gambar 3 diketahui bahwa pada komponen yang pertama KT sudah memenuhi semua indikator. Dimana KT mengidentifikasi konsep SPLDV yang ada pada permasalahan serta menggambarkan situasi matematis. KT juga menemukan hubungan antar variabel berdasarkan fakta yang ada pada soal serta membuat model matematika berdasarkan informasi yang ada pada soal.

Untuk komponen yang kedua KT juga sudah memenuhi semua indikator. Hal tersebut terlihat dari hasil jawaban KT pada gambar 3 bahwa pada komponen berpikir literasi matematika yang kedua: KT menggunakan metode eliminasi dan substitusi untuk memecahkan permasalahan yang ada pada soal. KT juga menggunakan informasi serta petunjuk yang ada untuk memecahkan permasalahan pada soal. Untuk menyelesaikan permasalahan tersebut KT juga mengolah data serta informasi yang ada.

Begitupun untuk komponen yang ketiga KT juga sudah memenuhi semua indikator. Hal tersebut terlihat dari jawaban KT pada gambar 3 bahwa siswa sudah menginterpretasikan hasil pemecahan masalahnya. KT juga menuliskan kesimpulan jawaban dari permasalahan yang 
ada pada soal. Dimana KT menuliskan jadi banyak ayam dan sapi adalah 10 dan 4 ekor. Jawaban yang dituliskan KT sudah benar dan tepat.

Hasil wawancara KT juga sejalan dengan pemaparan-pemaparan di atas. Dimana KT sudah mengetahui permasalahan yang ada pada soal. Sehingga KT menggunakan strategi tertentu untuk menyelesaikan soal dan menafsirkan serta mengevaluasi hasil jawabannya dengan baik dan tepat.

Berdasarkan pemaparan-pemaparan di atas dapat diketahui bahwa siswa dengan kemandirian belajar tinggi sudah memenuhi semua indikator komponen berpikir literasi matematika. Hal tersebut sejalan dengan penelitian Arum (2017) bahwa siswa dengan kemandirian belajar tinggi sudah mampu mengidentifikasi permasalahan dan informasi yang ada pada soal, merancang strategi yang tepat untuk menyelesaikan soal, memberikan alasan yang mendukung untuk jawabannya serta menyimpulkan hasil dari jawabannya. Penelitian Ekananda dkk. (2020) menyatakan bahwa siswa dengan kemandirian belajar tinggi dapat memahami, membuat rencana mengaitkan konsep dalam menyelesaikan permasalahan yang ada pada soal dan juga menuliskan kesimpulan hasil jawabannya. Penelitian Mayasari \& Rosyana (2019) menyatakan bahwa siswa kemandirian belajar tinggi menuliskan unsur yang diketahui, ditanyakan serta kesimpulan dari hasil jawabannya.

\section{PENUTUP}

\section{Kesimpulan}

Berdasarkan analisis hasil jawaban dan wawancara dapat diketahui bahwa siswa dengan kategori kemandirian belajar rendah, sedang dan tinggi mempunyai ketercapaian indikator berpikir literasi matematika yang berbeda-beda. Secara rinci, dapat diuraikan sebagai berikut:

a. Siswa dengan kategori kemandirian belajar rendah hanya memenuhi 2 indikator dari ketiga komponen proses berpikir literasi matematika pada materi SPLDV yaitu siswa menuliskan kesimpulan hasil jawabannya dengan benar, namun tidak menuliskan langkah-langkah penyelesaian serta alasan yang mendukung jawabannya dan pemikirannya.

b. Siswa dengan kategori kemandirian belajar sedang hampir sudah memenuhi semua indikator dari ketiga komponen proses berpikir literasi matematika pada materi SPLDV. Adapun indikator yang tidak terpenuhi yaitu siswa melakukan kesalahan dalam menuliskan pemodelan matematika yang menyebabkan kesimpulan dari hasil jawabannya kurang tepat dan juga tidak mengevaluasi hasil jawabannya. Serta siswa tidak menyadari adanya kesalahan dari hasil jawabannya oleh karena itu siswa tidak memperbaikinya.

c. Siswa dengan kategori kemandirian belajar tinggi memenuhi semua indikator dari komponen proses berpikir literasi matematika pada materi SPLDV yaitu siswa 
dapat mengidentifikasi informasi serta permasalahan yang ada pada soal, siswa menentukan strategi yang tepat untuk menyelesaikan soal, siswa juga membuat model matematika sesuai informasi yang ada pada soal, menuliskan langkah-langkah penyelesaian serta alasan yang mendukung hasil jawaban juga pemikirannya dan memeriksa kembali hasil jawabannya.

\section{Saran}

Penelitian ini mempunyai keterbatasan yaitu terbatas hanya pada analisis berpikir literasi matematika siswa berdasarkan kategori kemandirian belajar yaitu: rendah, sedang dan tinggi. Dimana subjek dari penelitian ini hanya terdiri dari tiga orang. Oleh karena itu berdasarkan hal tersebut, maka disarankan apabila akan mengkaji mengenai berpikir literasi matematika dapat menganalisis dengan faktorfaktor lain yang mempengaruhi kemampuan literasi matematika siswa selain kemandirian belajar. Serta pada materi lain dan juga untuk jumlah dari subjek penelitian dapat diperbanyak agar jawaban siswa lebih beragam serta terdapat perbandingan-perbandingan antar subjek penelitian.

\section{DAFTAR PUSTAKA}

Aini dkk. (2018). Analisis Berpikir Literasi Matematika Siswa dalam Menyelesaikan Soal Matematika pada Pokok Bahasan Pola Bilangan Berdasarkan Kecerdasan Majemuk. Kadikma, 9, 127-135.

Anwar, N. T. (2018). Peran Kemampuan Literasi Matematis pada Pembelajaran Matematika Abad-21. 1, 364-370.
Arum, R. P. (2017). Deskripsi Kemampuan Metakognisi Siswa SMA Negeri 1 Sokaraja dalam Menyelesaikan Soal Cerita Matematika Ditinjau dari Kemandirian Belajar. AlphaMath, 3(1).

Astuti dkk. (2018). Analisis Kemampuan Literasi Matematika Siswa Kelas VII SMP Swasta di Kota Kendari. Jurnal Penelitian Pendidikan Matematika, 6(1), 99-112.

Ekananda dkk. (2020). Analisis Kemampuan Pemecahan Masalah Matematis Ditinjau dari Kemandirian Belajar Siswa. Wilangan, 1(4), 367-382.

Indrawati, F. A., \& Wardono. (2019). Pengaruh Self Efficacy Terhadap Kemampuan Literasi Matematika dan Pembentukan Kemampuan 4C. Prisma, Prosiding Seminar Nasional Matematika, 2, 247-267.

Kholifasari dkk. (2020). Analisis Kemampuan Literasi Matematis Siswa Ditinjau dari Karakter Kemandirian Belajar Materi Aljabar. Jurnal Derivat, 7(2), 117-125.

Mayasari, \& Rosyana, T. (2019). Pengaruh Kemandirian Belajar Terhadap Kemampuan Pemecahan Masalah Matematis Siswa SMP Kota Bandung. Jurnal Cendekia: Jurnal Pendidikan Matematika, 3(1), 82-89.

OECD. (2019). Programme for International Student Assessment (PISA) Result From Pisa 2018 Indonesia-Country Note. I-III, 1-10.

Sari, R. H. N. (2015). Literasi Matematika: Apa, Mengapa dan Bagaimana? Seminar Nasional Matematika Dan Pendidikan Matematika UNY, 713-720.

Sulistyani dkk. (2020). Hubungan Kemandirian Belajar dengan Kemampuan Pemecahan Masalah Matematis. Jurnal Pendidikan Matematika, 11(1), 1-12.

Utami dkk. (2020). Kemampuan Literasi dalam Menyelesaikan Soal Cerita Siswa Kelas IX A. 
Prisma, Prosiding Seminar Nasional Matematika, 3, 626-633.

Wijayanti, P., \& Wardono. (2020). Analisis Literasi Matematika Ditinjau dari
Kemandirian Belajar Siswa SMP Pada

Pembelajaran DAPIC- Problem- Solving Pendekatan PMRI Berbatuan Schoology. Prisma, Prosiding Seminar Nasional Matematika, 3, 670-678. 